\title{
Outcomes of Surgically Treated Giant Pituitary Tumours
}

\author{
Michael D. Cusimano, Peter Kan, Farshad Nassiri, Jennifer Anderson, \\ Jeannette Goguen, Irene Vanek, Harley S. Smyth, Ronald Fenton, \\ Paul J. Muller, Kalman Kovacs
}

\begin{abstract}
Objective: To evaluate the outcomes of patients with giant pituitary tumours (GPTs) who underwent a purely binasal endoscopic transsphenoidal surgery (BETS) and compare their outcomes with those achieved through craniotomy and microscopic transsphenoidal surgery (MTS). Methods: Seventy-two consecutive patients with GPTs (greater than $10 \mathrm{~cm}^{3}$ in volume) who were treated surgically with BETS, craniotomy, or MTS from October 1994 to July 2009 were reviewed for clinical outcomes, degree of tumor resection, recurrence rates, and surgical complications. Results: The BETS group had significantly better mean reduction of tumor volume $(91 \%)$ than the craniotomy $(63 \%, \mathrm{p}=0.001)$, and the MTS $(63 \%, \mathrm{p}=0.010)$ groups. Gross total resection rates were also higher for BETS patients than for craniotomy patients $(\mathrm{p}=0.010)$. Improvements in vision and headaches were noted in $96 \%$ and $100 \%$ of patients in the BETS group, respectively; these rates were similar to those in the craniotomy and MTS groups. Of the four patients with hormone-secreting tumours in the BETS group, three remained in remission. The median length-of-stay (four days) for the BETS group was shorter $(\mathrm{p}=0.010)$, and surgical complications were less frequent $(\mathrm{p}=0.037)$ and less severe compared to the craniotomy group. There were no differences in the recurrence rates: 79\% percent of patients in the BETS group, 69\% in the craniotomy group, and 79\% in the MTS group were recurrence free at last follow-up $(p=0.829)$. Conclusions: Treatment of GPT with BETS offers excellent oncologic and clinical outcomes and can frequently obviate the need for craniotomy in these patients.
\end{abstract}

RÉSUMÉ: Résultats du traitement chirurgical des tumeurs géantes de l'hypophyse (TGH). Objectif : Le but de l'étude était d'évaluer les résultats de la chirurgie transsphénoïdale endoscopique binasale (CTEB), de la craniotomie et de la chirurgie transsphénoïdale par microscopie (CTM) chez des patients atteints de tumeurs géantes de l'hypophyse et de comparer les résultats obtenus suite à ces chirurgies. Méthode : Les dossiers de patients consécutifs atteints de TGH (volume supérieur à $10 \mathrm{~cm} 3$ ), qui ont été traités chirurgicalement soit par CTEB, craniotomie ou CTM d'octobre 1994 à juillet 2009, ont été révisés et les résultats cliniques, l'étendue de la résection, le taux de récidive et les complications chirurgicales ont été colligés. Résultats : Le groupe ayant subi une CTEB avait une diminution moyenne du volume de la tumeur qui était significativement meilleure (91\%) que celle de la craniotomie $(63 \% ; \mathrm{p}=0,001)$, et que le groupe $\mathrm{CM}(63 \% ; \mathrm{p}=0,010)$. Le taux global de résection était également plus élevé chez les patients du groupe CTEB que chez les patients qui avaient subi une craniotomie $(\mathrm{p}=0,010)$. Chez les patients du groupe CTEB, une amélioration de la vision et des céphalées ont été notées chez $96 \%$ et $100 \%$ des patients respectivement. Ces taux étaient similaires à ceux des deux autres groupes de patients. Trois des 4 patients atteints de tumeurs secrétant des hormones dans le groupe CTEB demeurent en rémission. La durée médiane de l'hospitalisation (4 jours) pour les patients du groupe CTEB était plus courte $(\mathrm{p}=0,010)$ et les complications chirurgicales moins fréquentes $(\mathrm{p}=0,037)$ et moins sévères par rapport au groupe de patients qui avaient subi une craniotomie. Nous n'avons constaté aucune différence dans les taux de récidive : $79 \%$ des patients du groupe CTEB, 69\% de ceux du groupe ayant subi une craniotomie et 79\% de ceux du groupe ayant subi une CTM n'avaient pas de récidive au moment du dernier examen de suivi $(\mathrm{p}=0,829)$ Conclusions : Le traitement d'une TGH par CTEB donne d'excellents résultats oncologiques et cliniques et peut souvent éviter une craniotomie chez ces patients.

Can J Neurol Sci. 2012; 39: 446-457

Giant pituitary tumours (GPTs) are rare tumours of $30 \mathrm{~mm}$ or more, that have major extensions into the suprasellar and parasellar compartments. ${ }^{1-7}$ Despite the major neurosurgical challenge that resecting GPTs presents, ${ }^{8-16}$ both transsphenoidal and transcranial approaches have been used. ${ }^{2,17,18}$ Transsphenoidal approaches offer a more direct route to the sellar components and can stay outside the arachnoid whenever possible. Transcranial approaches offer direct visualization of the suprasellar components but, because they must come from the subarachnoid position, visualizing the sellar contents can be difficult without drilling the planum sphenoidale or mobilizing the optic nerve.

Surgical morbidity and mortality for these lesions can be high, although the safety of the surgery has progressively improved, ${ }^{14-16,19,20}$ and an individualized approach of partial resection followed by radiation therapy has been proposed ${ }^{8}$ However, because these tumours are often gonadotrophic cell

\footnotetext{
From the Division of Neurosurgery (MDC, PK, FN, HSS, PJM), Department of Surgery, Department of Otorhinolaryngology (JA, RF), Division of Endocrinology (JG), Department of Medicine, Department of Ophthalmology (IV), Division of Pathology (KK), Department of Laboratory Medicine, St. Michael's Hospital, University of Toronto, Toronto, Ontario, Canada.

Received March 2, 2011. Final Revisions Submitted January 9, 2012. Correspondence to: Michael D. Cusimano, Division of Neurosurgery, St. Michael's Hospital, 30 Bond Street, Toronto, Ontario, M5B 1W8, Canada. Email: injuryprevention@smh.ca
} 
tumours with low proliferation rates, ${ }^{21}$ surgery can have profound long-term benefits without the potential morbidity associated with radiation therapy. 22,23

Over the last two decades, there have been significant advances in transsphenoidal surgery, including the development of the endonasal endoscopic transsphenoidal technique. ${ }^{24}$ In 1993, we developed the binasal transsphenoidal approach and described all its key features in 1996.25 This purely endoscopic approach was unique at the time because of the posterior septotomy that allowed the surgeon to use both nostrils to access and operate on lesions of the skull base using endoscopes for the entire operation. This advancement allowed surgeons to do bimanual surgery and expand their access to extensive lesions with a panoramic view beyond the sella. Many immediately began using this approach on larger lesions of the sella and central skull base. Since then a number of authors ${ }^{26-28}$ have written about this approach to deal with lesions in and beyond the sella and central skull base.

Goel et $\mathrm{al}^{2}$ in their study of craniotomy and microscopic transsphenoidal surgery (MTS) for GPTs, reported that radical surgery could provide reasonable recovery of vision and a satisfactory postoperative and long-term outcome. However, surgery was limited by cavernous sinus invasion of, and infiltrative growth around, the anterior cerebral artery complex. They also found that residual tumor in the cavernous sinus remained in the majority of cases, despite directed visualization with the microscope. The use of advanced endoscopic techniques with angled endoscopes has improved the visualization of aspects of the tumours that may be obscured with the microscopic approach. Whether the use of angled endoscopes portends an improved degree of resection has not been shown.

In a more recent report, Mortini et $\mathrm{al}^{3}$ described their experience with a series of giant pituitary adenomas treated with frontoorbitozygomatic and subfrontal craniotomy and transsphenoidal techniques. They used rigid endoscopes with 0 - and 30-degree lenses after removing a sublabial microscopic tumor to completely inspect the intrasellar and suprasellar space. They

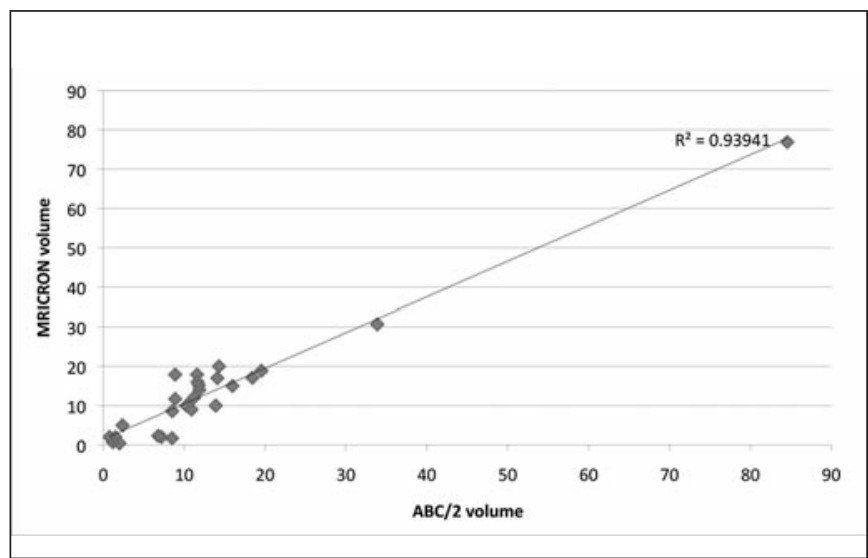

Figure 1: Correlation of tumor volume by two methods: $A B C / 2$ approximation and MRIcron software. used staged procedures for $17 \%$ of tumours that were particularly large. Although complete resection was achieved in only $15 \%$ of patients, vision improved in $75 \%$ of patients. The authors found that the invasion of the cavernous sinus and sphenoid sinus portended a poorer outcome. Whether a purely endoscopic approach could improve outcomes was not yet known.

The goals of this study were two-fold: 1) to evaluate the outcomes of a purely binasal endoscopic transsphenoidal (BETS) approach for the resection of GPTs, and 2) to compare the results of the BETS approach with those of craniotomy and MTS for patients with GPTs treated at our institution. We also aimed to better define the role of BETS to resecting GPTs and to distinguish its advantages and disadvantages from MTS and craniotomy.

\section{Materials ANd Methods}

\section{Tumor Volume Measurement}

Rather than using a single maximum tumor dimension as a measure of tumor size, we calculated the volume of the tumor. We measured actual tumor volume using MRIcron software (http://www.cabiatl.com/mricro/mricron/index.html) on all digitized magnetic resonance images (MRI) that used digital images and communications in medicine (DICOM) data. When digitized MRIs were not available, an ellipsoid shape, which is half the product of the maximal anteroposterior, lateral, and craniocaudal dimension of the mass (called the $\mathrm{ABC} / 2$ method), as recorded by the radiologist, was used as the tumour volume. This method has been validated as a method of calculating volume in animal models, in human traumatic brain injury studies, and for other human tumours. ${ }^{11,15,29-33}$ To test its validity for human pituitary tumours, we correlated the volumes from the $\mathrm{ABC} / 2$ method with the volumes from MRIcron. Our results show that the $\mathrm{ABC} / 2$ method for approximating tumor volume correlates highly with the volume obtained from software analyses $\left(\mathrm{r}^{2}=0.939\right.$, see Figure 1). The $\mathrm{ABC} / 2$ method, which takes about one minute to calculate, is an excellent substitute for manual volume measurements by software or Cavalieri's principle, ${ }^{34}$ which may take up to a few minutes per image. We defined GPT as a pituitary tumor with a volume of $10 \mathrm{~cm}^{3}$ or more, when calculated with this method. Using this definition, the largest dimension of the GPT was at least $30 \mathrm{~mm}$, as defined by Laws and Jane, ${ }^{6,7}$ Garibi et al ${ }^{1}$ and Mohr et al.${ }^{14}$ Postoperative residual volumes of tumours were similarly recorded. Figures 2 , 3 , and 4 show examples of preoperative and postoperative sagittal and coronal MRI images of patients with gross total resection (GTR), 90\% tumor-volume reduction, and 57\% tumorvolume reduction, respectively.

\section{Patients' Characteristics}

Baseline clinical information, presenting symptoms, visual and endocrine assessments, and confounding factors, including tumor pathology, tumor size, prior treatments, and cavernous sinus invasion (defined as greater than 50\% of intracavernous carotid encasement as identified with preoperative MRI, i.e. Knosp grade 3 or 4$)^{33,35}$ were recorded for each patient who underwent surgery for a GPT from October 1994 to July 2009 at our institution who had a minimum follow-up of one year. 


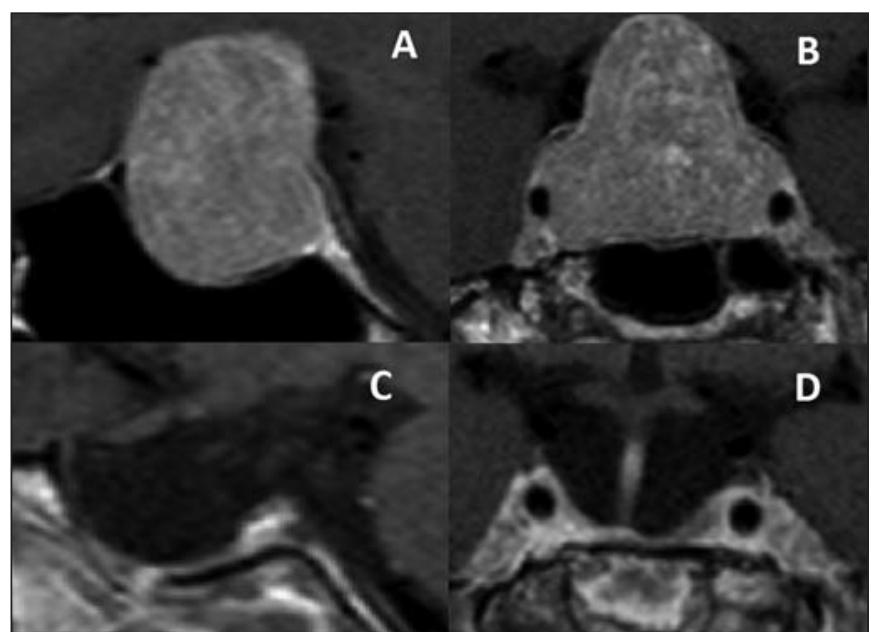

Figure 2: T1-weighted sagittal $(A)$ and coronal $(B)$ magnetic resonance imaging (MRI) scans showing a giant pituitary tumor (GPT) with preoperative volume of $11.88 \mathrm{~cm}^{3}$. T1-weighted sagittal $(C)$ and coronal (D) MRI scans obtained after binasal endoscopic transsphenoidal surgery showing gross total resection of the GPT.

Patients were divided into one of three groups (BETS, craniotomy, or MTS) according to the surgical approach they underwent which was largely due to surgeon and patient preference. If there was a significant lateral extension of the tumour that the surgeon felt was important to resect in addition to a midline component, transcranial approaches were favoured

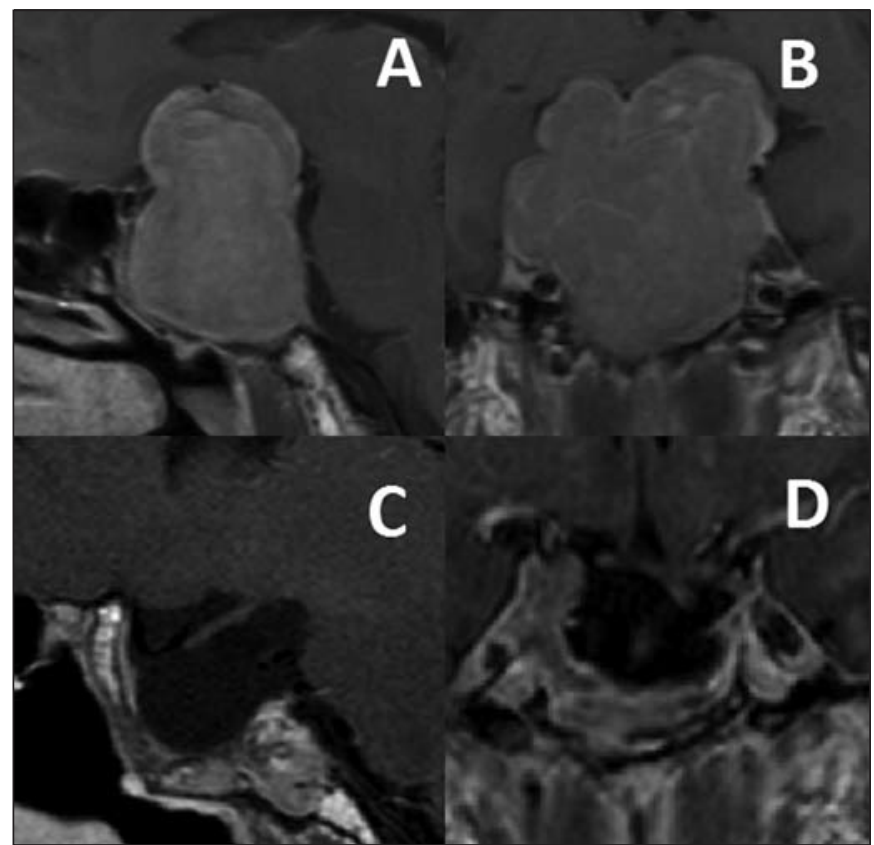

Figure 3: T1-weighted sagittal $(A)$ and coronal $(B)$ magnetic resonance imaging (MRI) scans showing a giant pituitary tumor with a preoperative volume of $84.56 \mathrm{~cm}^{3} . T 1$-weighted sagittal $(C)$ and coronal (D) MRI scans obtained after binasal endoscopic transsphenoidal surgery showing a residual tumor with a volume of $8.52 \mathrm{~cm}^{3}$, a $90 \%$ tumor-volume reduction. over transsphenoidal ones. Prior to 2002, there were six BETS cases, seven craniotomy cases and nine MTS cases in this series.

Clinical outcomes included degree of resection, recurrence (defined as growth in tumor volume), need for adjuvant therapy, improvement of clinical symptoms and vision, postoperative endocrine function, complications, and length of stay (LOS). Both intraoperative and perioperative complications were also recorded.

\section{Surgical Technique}

Binasal endoscopic transsphenoidal was done according to our previously published technique ${ }^{25}$ and included a posterior septotomy, purely binasal endoscopic approach, and wherever necessary, extended exposures to clival, parasellar, or planum sphenoidale. Fluoroscopy and nasal speculum were used for only the first patient. We routinely used neuronavigation (BrainLab) rather than fluoroscopy, and explored cavernous sinus and suprasellar tumor extension endoscopically using angled endoscopes (30- and 45-degree lenses on a 4-mm rigid Storz endoscope) and angled instruments. Since 1996, we have used microvascular doppler ultrasound to confirm the location of the internal carotid arteries. For reconstruction, we replace bone, and when a cerebrospinal fluid (CSF) leak occurs, we use multilayer reconstructions with fascia lata and fat, and since 1998, vascularized mucosal flaps. Choice of surgical approach for this patient series was largely the preference of the operating surgeon (MDC, PJM, HSS), but one surgeon (MDC) did all endoscopic approaches.

Microscopic transsphenoidal surgery was done via a transseptal or transnasal approach using Hardy specula with an operating microscope. Craniotomy was done either through a

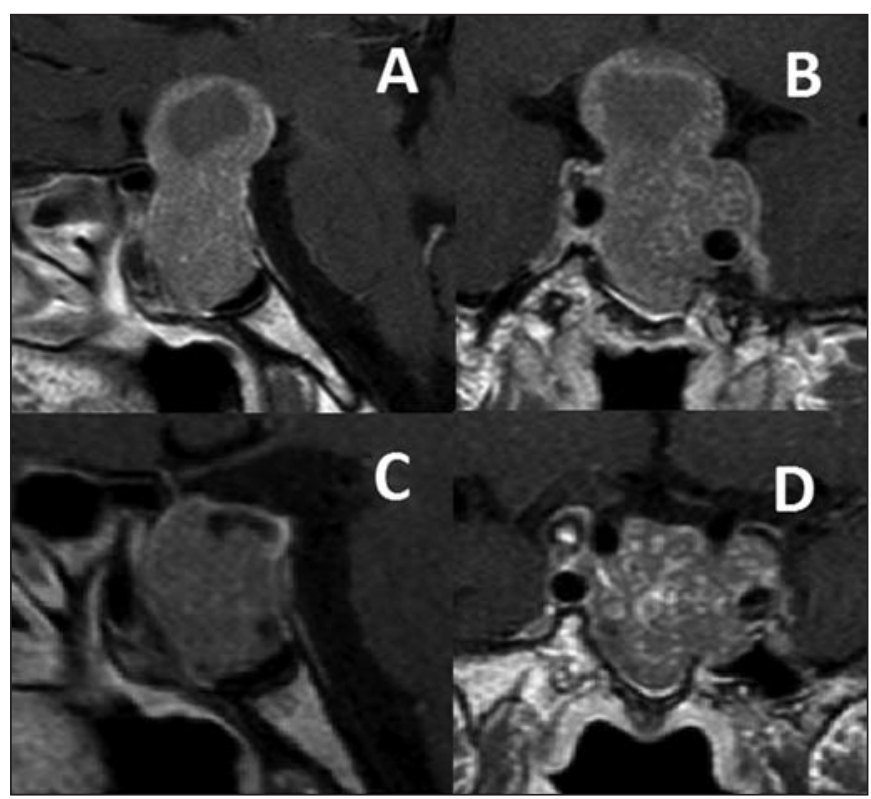

Figure 4: T1-weighted sagittal (A) and coronal (B) magnetic resonance imaging (MRI) scans showing a giant pituitary tumor with a preoperative volume of $15.40 \mathrm{~cm}^{3} . T 1$-weighted sagittal $(C)$ and coronal (D) MRI scans obtained after craniotomy showing a residual tumor with a volume of $6.6 \mathrm{~cm}^{3}$, a $57 \%$ tumor-volume reduction. 
subfrontal (3 patients), an orbiotozygomatic (4 patients), or a pterional (22 patients) approach.

\section{Statistical Analysis}

Fisher Exact tests were used to compare all qualitative baseline characteristics and the proportion of patients with GTR, recurrence, clinical improvement, adjuvant therapy, and complications in the three groups. A one-way, two-tailed analysis of variance (ANOVA) was used to compare preoperative tumor volume, preoperative maximum tumor dimension, postoperative maximum tumor dimension, tumor-volume reduction, and time to recurrence. A Kruskal-Wallis Test was used to compare the median LOS of the three groups. Calculations were done with SPSS 15.0 software (IBM, Somers, New York), and a p-value less than 0.05 was considered significant. During volumereduction analyses, one patient from the BETS group was excluded because of poor-quality postoperative MRI images.

\section{RESULTS}

\section{Baseline Characteristics}

A total of 72 patients with a minimum follow-up of one year underwent an operation for a GPT at our institution from October 1994 to July 2009. Of these 72 patients, 29 (40.3\%) underwent BETS, 29 (40.3\%) underwent craniotomy, and 14 (19.4\%) underwent MTS. The average overall follow-up was 6.16 years (range 1.0-13.3 years). The mean maximal tumor dimension was $3.97 \mathrm{~cm}$ (range $3-6 \mathrm{~cm}$ ).

The BETS group had 25 nonfunctional and 4 functional tumours (three growth hormone-secreting [GH-secreting], and one prolactin-secreting [PRL-secreting]). Eight (27.6\%) of the 29 patients had prior surgery for their pituitary tumours (one patient had also received radiation therapy), and one $(3.4 \%)$ patient received prior medical treatment. In the BETS group, prior surgery included one BETS, three craniotomy, four MTS. Cavernous sinus involvement (Knosp grade 3 or 4) was present in $15(51.7 \%)$ patients. The mean preoperative tumor volume and maximal dimension $\left( \pm\right.$ SD) were $19.95 \pm 15.69 \mathrm{~cm}^{3}$ and 4.04 $\pm 0.75 \mathrm{~cm}$, respectively.

The craniotomy group had 27 nonfunctional and 2 functional tumours (one adrenocorticotrophic hormone-secreting and one GH-secreting). Twelve (41.4\%) of 29 patients had prior surgery (seven also received radiation therapy), and two (6.9\%) patients had prior medical treatment (one had prior surgery, and one had prior surgery and radiation therapy). In the craniotomy group, prior surgery included two BETS, seven craniotomy, three MTS. Cavernous sinus involvement was present in $15(51.7 \%)$ patients. The mean preoperative tumor volume and maximal dimension $( \pm \mathrm{SD})$ were $22.21 \pm 12.40 \mathrm{~cm}^{3}$ and $4.03 \pm 0.69 \mathrm{~cm}$, respectively.

The MTS group had 12 nonfunctional and 2 functional tumours (2 PRL-secreting). Three $(21.4 \%)$ of 14 patients had prior surgery (one patient also received radiation therapy), and two $(14.3 \%)$ patients received prior medical treatment. In the MTS group, prior surgery included one craniotomy, three MTS. Cavernous sinus involvement was present in $11(78.6 \%)$ patients. The mean preoperative tumor volume and maximal dimension $( \pm \mathrm{SD})$ were $16.83 \pm 5.49 \mathrm{~cm}^{3}$ and $3.66 \pm 0.52 \mathrm{~cm}$, respectively.
The baseline characteristics and presenting symptoms of the three groups of patients are summarized in Table 1. Most of the differences among the baseline characteristics of patients treated with each of the approaches were not significant. However, the proportion of males in the MTS group was higher than that in the craniotomy group $(\mathrm{p}=0.009)$, and more patients in the craniotomy group had received prior radiation therapy than those in the BETS group $(p=0.049)$. The baseline characteristics of the BETS group and MTS group were not significantly different (Table 1).

\section{Surgical Outcomes \\ BETS group}

The surgical and clinical outcomes for the three groups are summarized in Table 2. In the BETS group, the mean tumorvolume reduction was $91 \%$ (median $95 \%$, range 43-100\%) and six $(21 \%)$ patients had a GTR. The mean length of follow-up was 5.41 (range 1.0-13.3 years); total follow-up was 51,421 patient days from the date of surgery. Twenty-two (76\%) patients were recurrence free at last follow-up. Of the seven patients who had a recurrence of the tumor, pathological examination showed that two patients had invasive silent subtype III adenoma and one patient had invasive silent subtype II corticotroph adenoma. The mean time to recurrence was 2.3 years (median 2.4 years, range $0.3-4.3$ years). Of the seven patients who had a recurrence of the tumor, none initially achieved GTR and six (86\%) had not received prior surgery. Eight (28\%) of the 29 patients were given adjuvant therapy (four radiation, two medical, two reoperation). Radiation was given to treat residual tumor (one patient) and recurring tumor (two patients), and to alleviate visual disturbances (one patient). Medical treatment (octreotide, cabergoline) was given for tumor growth in two patients. Two patients received a second operation to alleviate visual disturbances and to debulk residual tumor. Improvements in vision and headaches were noted in $96 \%$ and $100 \%$ of patients, respectively. Of the four patients with hormone-secreting tumours, three remained in remission. Although a GTR was not observed in the patients who underwent prior surgery, the average volume reduction and recurrence rate were not different between those who underwent BETS for the second operation ( $p$ $=0.235$ ) and those who underwent primary endoscopic resection $(\mathrm{p}=0.639)$. Cerebrospinal fluid leakage occurred in eight patients: four patients required intraoperative fascia lata repair; one patient required reoperation for repair. The median LOS was 4.0 days (mean 6.6 days), and, aside from CSF leaks, 2 (7\%) of 29 patients had minor surgical complications. Table 3 lists the complications that occurred in the BETS group.

\section{Craniotomy group}

In the craniotomy group, the mean tumor-volume reduction was $63 \%$ (median 64\%, range 21-98\%), and no patients had GTR. The mean length of follow-up was 6.55 years (range 1.012.3 years); total follow-up was 67,006 patient days from the date of surgery. Twenty (69\%) patients were recurrence free at last follow-up. Of the nine patients who had a recurrence, one had an invasive silent subtype II corticotroph adenoma. Mean time to recurrence was 2.5 years (median 2.1 years, range 1.0 4.5 years). Of those who had a recurrence, none initially 
Table 1: Baseline Characteristics

\begin{tabular}{|c|c|c|c|c|c|}
\hline \multicolumn{2}{|c|}{ BASELINE CHARACTERISTICS } & BETS (29) & MTS (14) & $\begin{array}{l}\text { CRANIOTOMY } \\
\text { (29) }\end{array}$ & P-VALUE \\
\hline \multirow[t]{2}{*}{ Sex } & Male & $55 \%(16)$ & $71.4 \%(10)$ & $27.6 \%(8)$ & \multirow[t]{2}{*}{0.012} \\
\hline & Female & $45 \%(13)$ & $28.6 \%(4)$ & $72.4 \%(21)$ & \\
\hline \multirow{2}{*}{$\begin{array}{l}\text { Preop visual } \\
\text { disturbance }\end{array}$} & Yes & $90 \%(26)$ & $100 \%(14)$ & $96.6 \%(28)$ & \multirow[t]{2}{*}{0.519} \\
\hline & No & $10 \%(3)$ & $0 \%(0)$ & $3.4 \%(1)$ & \\
\hline \multirow{2}{*}{$\begin{array}{l}\text { Preop } \\
\text { cranioneuropathy }\end{array}$} & Yes & $13.8 \%(4)$ & $28.6 \%(4)$ & $10 \%(3)$ & \multirow[t]{2}{*}{0.383} \\
\hline & $\mathrm{No}$ & $86.2 \%(25)$ & $71.4 \%(10)$ & $90 \%(26)$ & \\
\hline \multirow[t]{2}{*}{ Preop headache } & Yes & $48.2 \%(14)$ & $64.3 \%(9)$ & $37.9 \%(11)$ & \multirow[t]{2}{*}{0.269} \\
\hline & $\mathrm{No}$ & $51.8 \%(15)$ & $35.7 \%(5)$ & $62.1 \%(18)$ & \\
\hline \multirow{2}{*}{$\begin{array}{l}\text { Tumour } \\
\text { classification }\end{array}$} & Functional & $17.2 \%(4)$ & $16.7 \%(2)$ & $6.9 \%(2)$ & \multirow[t]{2}{*}{0.695} \\
\hline & Non-functional & $82.8 \%(25)$ & $83.3 \%(12)$ & $93.1 \%(27)$ & \\
\hline \multirow[t]{2}{*}{ Apoplexy } & Yes & $6.9 \%(2)$ & $21.4 \%(3)$ & $6.9 \%(2)$ & \multirow[t]{2}{*}{0.303} \\
\hline & No & $93.1 \%(27)$ & $78.6 \%(11)$ & $93.1 \%(27)$ & \\
\hline \multirow[t]{2}{*}{ Prior surgery } & Yes & $27.6 \%(8)$ & $21.4 \%(3)$ & $41.4 \%(12)$ & \multirow[t]{2}{*}{0.387} \\
\hline & No & $72.4 \%(21)$ & $78.6 \%(11)$ & $58.6 \%(17)$ & \\
\hline \multirow[t]{2}{*}{ Prior radiotherapy } & Yes & $3.8 \%(1)$ & $7.1 \%(1)$ & $24.1 \%(7)$ & \multirow[t]{2}{*}{0.041} \\
\hline & $\mathrm{No}$ & $96.2 \%(28)$ & $92.9 \%(13)$ & $75.9 \%(22)$ & \\
\hline \multirow{2}{*}{$\begin{array}{l}\text { Prior medical } \\
\text { treatment }\end{array}$} & Yes & $3.4 \%(1)$ & $16.7 \%(2)$ & $6.9 \%(2)$ & \multirow[t]{2}{*}{0.411} \\
\hline & No & $96.6 \%(28)$ & $83.3 \%(12)$ & $93.1 \%(27)$ & \\
\hline \multirow{2}{*}{$\begin{array}{l}\text { Cavernous sinus } \\
\text { invasion }\end{array}$} & Yes & $51.8 \%(15)$ & $78.6 \%(11)$ & $51.8 \%(15)$ & \multirow[t]{2}{*}{0.195} \\
\hline & No & $48.2 \%(14)$ & $21.4 \%(3)$ & $48.2 \%(14)$ & \\
\hline \multirow{5}{*}{$\begin{array}{l}\text { Tumor pre-op } \\
\text { volume }\left(\mathrm{cm}^{3}\right)\end{array}$} & Mean & 19.95 & 16.83 & 22.21 & \multirow[t]{5}{*}{0.442} \\
\hline & Median & 13.98 & 14.81 & 18.12 & \\
\hline & $\operatorname{Max}$ & 84.56 & 30.7 & 56.4 & \\
\hline & Min & 10 & 11.5 & 10.1 & \\
\hline & $\begin{array}{l}\text { Standard } \\
\text { deviation }\end{array}$ & 15.69 & 5.49 & 12.40 & \\
\hline \multirow{5}{*}{$\begin{array}{l}\text { Tumor pre-op } \\
\text { maximum dimension } \\
(\mathrm{cm})\end{array}$} & Mean & 4.04 & 3.66 & 4.03 & \multirow[t]{5}{*}{0.194} \\
\hline & Median & 3.9 & 3.6 & 4 & \\
\hline & Max & 6 & 5 & 5 & \\
\hline & Min & 3 & 3 & 3 & \\
\hline & $\begin{array}{l}\text { Standard } \\
\text { deviation }\end{array}$ & 0.75 & 0.52 & 0.69 & \\
\hline \multirow[t]{5}{*}{ Age } & Mean & 50.3 & 48.9 & 53.5 & \multirow{5}{*}{0.568} \\
\hline & Median & 52 & 43 & 56 & \\
\hline & $\operatorname{Max}$ & 83 & 83 & 75 & \\
\hline & Min & 16 & 19 & 32 & \\
\hline & $\begin{array}{l}\text { Standard } \\
\text { deviation }\end{array}$ & 15.4 & 19.6 & 11.8 & \\
\hline
\end{tabular}

BETS $=$ binasal endoscopic transsphenoidal approach, $\mathrm{MTS}=$ microscopic transsphenoidal approach The p-value is the result from the comparison of the outcome that is listed (column 1) between the three groups (columns 3, 4, 5). For all categorical data, p-values are results of comparison of counts (Fisher Exact tests). For all quantitative data, p-values are results of comparison of means (ANOVA). For more information on the results of the significant comparisons refer to the results text.

achieved GTR and four (44\%) of the nine patients had received prior surgery. Twenty (69\%) of the 29 patients required adjuvant therapy: 6 patients required reoperation for tumor growth; 13 patients, radiotherapy; and 1 patient, medicine. Twenty-one $(72 \%)$ and nine $(82 \%)$ patients had improved vision and headaches, respectively. Both patients with hormone-secreting tumours remained in remission at last follow-up. The median LOS was 9.0 days (mean 16.6 days). Nine (31\%) patients developed a perioperative complication. Table 3 lists the complications that occurred in the craniotomy group.

\section{MTS group}

In the MTS group, the mean tumor-volume reduction was $63 \%$ (median $61 \%$, range $20-100 \%$ ). Two (14\%) of 14 patients achieved a GTR. The mean length of follow-up was 6.91 years (range 1.0-10.8 years), and total follow-up was 29,434 patient days from the date of surgery. Eleven (79\%) patients were recurrence free at last follow-up. Of the three patients who had a recurrence, one had an invasive silent subtype I corticotroph adenoma. None of the patients who recurred achieved GTR and one had undergone prior surgery. Eight $(57 \%)$ of 14 patients required adjuvant therapy; three of these patients required reoperation for tumor growth. Eighty-six percent and 100\% of patients who underwent MTS had improved vision and headaches, respectively. Of the two patients with hormonesecreting tumours, one remained in remission while the other did not, despite adjuvant medical therapy. Cerebrospinal fluid leakage occurred in two patients intraoperatively whom required facia lata repair. The CSF leakage occurred in four patients post- 
Table 2: Outcomes

\begin{tabular}{|c|c|c|c|c|c|}
\hline OUTCOMES & & BETS (29) & MTS (14) & $\begin{array}{l}\text { CRANIOTOMY } \\
\text { (29) }\end{array}$ & P-VALUE \\
\hline \multirow[t]{2}{*}{ Transfusion } & Yes & $3.4 \%(1)$ & $14.3 \%(2)$ & $10.3 \%(3)$ & \multirow[t]{2}{*}{0.552} \\
\hline & No & $96.6 \%(28)$ & $85.7 \%(12)$ & $89.7 \%(26)$ & \\
\hline \multirow[t]{2}{*}{ Gross total removal } & Yes & $20.7 \%(6)$ & $14.3 \%(2)$ & $0 \%(0)$ & \multirow[t]{2}{*}{0.028} \\
\hline & No & $79.3 \%(23)$ & $85.7 \%(12)$ & $100 \%(29)$ & \\
\hline \multirow[t]{2}{*}{ Recurrence } & Yes & $24.1 \%(7)$ & $21.4 \%(3)$ & $31.0 \%(9)$ & \multirow[t]{2}{*}{0.829} \\
\hline & No & $75.9 \%(22)$ & $78.6 \%(11)$ & $69.0 \%(20)$ & \\
\hline \multirow[t]{2}{*}{ Adjuvant Therapy } & Yes & $27.6 \%(8)$ & $57.1 \%(8)$ & $68.9 \%(20)$ & \multirow[t]{2}{*}{0.005} \\
\hline & No & $72.4 \%(21)$ & $42.9 \%(6)$ & $31.1 \%(9)$ & \\
\hline \multirow[t]{2}{*}{ Visual improvement* } & Yes & $96.2 \%(25)$ & $85.7 \%(12)$ & $72.4 \%(21)$ & \multirow[t]{2}{*}{0.096} \\
\hline & No & $3.8 \%(1)$ & $14.3 \%(2)$ & $27.6 \%(7)$ & \\
\hline \multirow{2}{*}{$\begin{array}{l}\text { Headache } \\
\text { improvement* }\end{array}$} & Yes & $100 \%(14)$ & $100 \%(9)$ & $81.8 \%(9)$ & \multirow[t]{2}{*}{0.064} \\
\hline & No & $0 \%(0)$ & $0 \%(0)$ & $18.2 \%(2)$ & \\
\hline \multirow{2}{*}{$\begin{array}{l}\text { Endocrine } \\
\text { improvement* }\end{array}$} & Yes & $41.2 \%(7)$ & $14.3 \%(1)$ & $14.3 \%(2)$ & \multirow[t]{2}{*}{0.268} \\
\hline & No & $58.8 \%(10)$ & $85.7 \%(6)$ & $85.7 \%(12)$ & \\
\hline \multirow{2}{*}{$\begin{array}{l}\text { New hormone } \\
\text { replacement }\end{array}$} & Yes & $31.0 \%(9)$ & $35.7 \%(5)$ & $41.4 \%(12)$ & \multirow[t]{2}{*}{0.272} \\
\hline & No & $69.0 \%(20)$ & $64.3 \%(9)$ & $58.6 \%(17)$ & \\
\hline \multirow{2}{*}{$\begin{array}{l}\text { Cranioneuropathy } \\
\text { Improvement* }\end{array}$} & Yes & $100 \%(4)$ & $100 \%(4)$ & $66.7 \%(2)$ & \multirow[t]{2}{*}{0.737} \\
\hline & No & $0 \%(0)$ & $0 \%(0)$ & $33.3 \%(1)$ & \\
\hline \multirow[t]{2}{*}{ Permanent DI } & Yes & $7.0 \%(2)$ & $16.7 \%(2)$ & $10.3 \%(3)$ & \multirow[t]{2}{*}{0.873} \\
\hline & No & $93.0 \%(27)$ & $83.3 \%(12)$ & $89.7 \%(26)$ & \\
\hline \multirow[t]{2}{*}{ Complications } & Yes & $7.0 \%(2)$ & $7.1 \%(1)$ & $31.0 \%(9)$ & \multirow[t]{2}{*}{0.037} \\
\hline & No & $93.0 \%(27)$ & $92.8 \%(13)$ & $69.0 \%(20)$ & \\
\hline \multirow[t]{5}{*}{ \% volume reduction } & Mean & 90.6 & 63.2 & 62.6 & \multirow[t]{5}{*}{0.001} \\
\hline & Median & 95.0 & 61.9 & 64.4 & \\
\hline & Max & 100 & 100 & 98.3 & \\
\hline & Min & 43.18 & 20 & 21.6 & \\
\hline & $\begin{array}{l}\text { Standard } \\
\text { deviation }\end{array}$ & 13.09 & 28.28 & 24.6 & \\
\hline \multirow{5}{*}{$\begin{array}{l}\text { Time to recurrence } \\
\text { (years) }\end{array}$} & Mean & 2.32 & 1.6 & 2.49 & 0.099 \\
\hline & Median & 2.4 & 1.8 & 2.1 & \\
\hline & $\operatorname{Max}$ & 4.3 & 2.2 & 4.5 & \\
\hline & Min & 0.33 & 0.8 & 1 & \\
\hline & $\begin{array}{l}\text { Standard } \\
\text { deviation }\end{array}$ & 1.48 & 0.72 & 1.21 & \\
\hline Length of stay (days) & Mean & 6.58 & 5.57 & 16.57 & 0.153 \\
\hline & Median & 4 & 4 & 9 & \\
\hline & Max & 52 & 13 & 184 & \\
\hline & Min & 2 & 0 & 2 & \\
\hline & $\begin{array}{l}\text { Standard } \\
\text { deviation }\end{array}$ & 9.14 & 3.83 & 33.07 & \\
\hline Length of follow-up & Mean & 5.41 & 6.91 & 6.55 & 0.395 \\
\hline (years) & Median & 4.5 & 6.9 & 6.3 & \\
\hline & $\operatorname{Max}$ & 13.3 & 10.8 & 12.3 & \\
\hline & Min & 1 & 1 & 1 & \\
\hline & $\begin{array}{l}\text { Standard } \\
\text { Deviation }\end{array}$ & 3.16 & 1.95 & 3.31 & \\
\hline
\end{tabular}

*Improvements in headache, cranioneuropathy, vision and endocrine function were based on rates of cranioneuropathy, vision, endocrinopathy and headaches preoperatively. BETS= binasal endoscopic transsphenoidal approach, MTS =transsphenoidal microscopic approach, DI = Diabetes Insipidus. The p-value is the result from the comparison of the outcome that is listed (column 1) between the three groups (columns 3, 4, 5). For all categorical data, p-values are results of comparison of counts (Fisher Exact tests). For all quantitative data, p-values are results of comparison of means (ANOVA). For more information on the results of the significant comparisons refer to the results text.

operatively and all four cases resolved without repair. One patient developed bacteremia (Table 3).

\section{Comparison of outcomes for the three groups of patients}

The degree of tumor resection differed significantly among the three groups $(\mathrm{p}=0.001, \mathrm{df}=70)$. Tumor-volume reduction in the BETS group (90.6\%) was significantly better than that in the craniotomy $(62.6 \%, \mathrm{p}=0.001)$ and MTS $(63.2 \%, \mathrm{p}=0.010)$ groups. The BETS group also achieved more GTR (20.7\%) than the craniotomy group $(0 \%, \mathrm{p}=0.010)$. The MTS group $(63.2 \%$ and $14.3 \%)$, however, did not have any significant greater degree of tumor-volume reduction ( $\mathrm{p}=0.943$ ) or greater rate of GTR ( $\mathrm{p}$ $=0.100)$ than the craniotomy group $(62.6 \%$ and $0 \%)$. When patients were restricted to having virgin tumors without any 
Table 3: Perioperative complications

\begin{tabular}{llll}
\hline COMPLICATIONS & BETS (29) * & MTS (14) & CRANIOTOMY (29) *** \\
\hline Pulmonary embolism & $6.9 \%(2)$ & $0 \%(0)$ & $3.4 \%(1)$ \\
\hline Deep vein thrombosis & $6.9 \%(1)$ & $0 \%(0)$ & $0 \%(0)$ \\
\hline Hydrocephalus & $0 \%(0)$ & $0 \%(0)$ & $3.4 \%(1)$ \\
\hline Subdural hygroma & $0 \%(0)$ & $0 \%(0)$ & $3.4 \%(1)$ \\
\hline Vasospasm & $0 \%(0)$ & $0 \%(0)$ & $3.4 \%(1)$ \\
\hline Post-operative hematoma & $0 \%(0)$ & $0 \%(0)$ & $13.8 \%(4)$ \\
\hline Bacteremia & $0 \%(0)$ & $7.1 \%(1)$ & $3.4 \%(1)$ \\
\hline Death & $0 \%(0)$ & $0 \%(0)$ & $3.4 \%(1)$ \\
\hline
\end{tabular}

* 1 BETS patient had developed both pulmonary embolism and deep vein thrombosis, another patient developed both CSF leak requiring reoperation and pulmonary embolism; **1 craniotomy patient developed both subdural hygroma and subdural hematoma. BETS= binasal endoscopic transsphenoidal approach, MTS=transsphenoidal microscopic approach

prior radiation therapy, there still was a significant difference in degree of tumor debulking and rates of GTR $(p=0.001)$. In this restricted group, the degree of tumor debulking and rates of GTR were higher for the BETS group $(93.16 \%$ and $28.6 \%)$ than for the craniotomy group $(71.2 \%$ and $0 \%,(p=0.001$ and $\mathrm{p}=0.027)$. There was also better tumor resection with BETS $(93.16 \%)$ than with MTS $(70.8 \%, p=0.038))$. Recurrence rates $(p=0.829)$ and the times to recurrence $(\mathrm{p}=0.091)$ were not significantly different between all three groups, but postoperative adjuvant therapy was more commonly administered in the craniotomy and MTS groups than in the BETS group ( $p=0.005)$. The proportion of patients with improvements in vision, headaches, and endocrine levels was similar among the three groups, but median LOS was longest in the craniotomy group $(\mathrm{p}=0.010$, $\mathrm{df}=2$ ). Patients in the craniotomy group had more perioperative complications than patients in the MTS or BETS groups $(\mathrm{p}=$ 0.037). These complications tended to be more severe (Table 3 ) and the effects of early complications were reflected in the much longer LOS in the craniotomy group.

\section{Discussion}

Surgery remains the first line of treatment of GPTs, with the exception of prolactinomas, which we routinely treat initially with dopamine agonists. However, resistance or intolerance to medical therapy is an indication for surgical management of macroprolactinomas. Both transsphenoidal and transcranial approaches have been used for these challenging GPTs, which often invade parasellar, suprasellar, presellar, and clival regions. Traditionally, tumor size was considered the main indication for craniotomy. Our study shows clearly that tumor size alone is not an indication for the use of one approach over another. In fact, the results at our institution indicate that craniotomy was inferior to BETS in the degree of tumor resection achieved and resulted in much longer hospital stays.

\section{Definition of Giant Pituitary Tumor}

Although they are seen in most surgical series of pituitary adenomas, GPTs are rare; incidences of 6-21\% for all pituitary tumours have been reported..$^{3,10,15,31}$ The large variability in the incidence of GPTs is partially the result of different referral patterns and partially the lack of a consistent definition of what constitutes a GPT. Until now, authors have considered only a single dimension, the maximum diameter of the lesion, rather than volume as a measure of size in their definition. Hardy, ${ }^{36}$ Mohr et al, ${ }^{14}$ Laws and Jane, ${ }^{6}$ Jane and Laws, ${ }^{7}$ and others ${ }^{1,15}$ have defined GPT as tumours with a maximum dimension of greater than $30 \mathrm{~mm}$, whereas others define giant as tumours greater than $40 \mathrm{~mm},{ }^{2,3,17,18}$ or those extending less than $6 \mathrm{~mm}$ from the foramen of Monro. ${ }^{4}$ To date, we are the first to use an MRIacquired volume-based definition for GPT. In our study, we defined the size of the tumor from an estimate of its volume because volume more accurately represents the true size of the tumor than a single dimension. Moreover, unlike a linear assessment, a volumetric measurement allows surgeons and radiologists to quantify the degree of tumor resection after surgery. From an oncologic perspective, patients are often most interested in how much of the tumor was removed. We chose a volume of $10 \mathrm{~cm}^{3}$ because we found that at this volume most tumours demonstrated third ventricular compression (see Figures 2, 3, and 4). Further, all tumours with a minimum volume of $10 \mathrm{~cm}^{3}$ met the GPT criterion of at least $30 \mathrm{~mm}$ set by Mohr et al, ${ }^{14}$ Hardy, ${ }^{36}$ Laws and Jane, ${ }^{6}$ and Garibi et al. ${ }^{1}$ The average maximum tumor dimension was $3.97 \mathrm{~cm}$. Future reports of series should use a consistent definition to facilitate communication.

\section{Surgical Approaches}

The transsphenoidal approach offers the advantage of a lower morbidity ${ }^{17}$ and a more direct route to the intrasellar component than transcranial approaches. The limitations of microscopic transsphenoidal approaches (transseptal, transnasal, sublabial) include the inability to visualize lateral structures because of the straight zero-degree angle of the light emanating from the surgical microscope. In contrast, a variety of endoscopes with angled lenses (e.g., 30-, 45-, 70-degree) can be used to visualize laterally and superiorly placed lesions. We routinely used these lenses with a series of angled instruments to access the areas that were not visible with the microscopic transsphenoidal approach. Using these scopes, the contralateral visualization allowed by the posterior septotomy greatly facilitated access to these 
lesions. Further, drilling the pterygoid plate and removing the bone lateral to the internal carotid artery prominence transsphenoidally and opening the dura lateral to the internal carotid artery also facilitated resection of these lesions. Consistent with these maneuvers, our data showed significantly greater volume reduction with endoscopic than microscopic transsphenoidal surgery.

The transcranial approach, on the other hand, can be more effective when there is a narrow waist at the diaphragma sellae (the so-called snowman appearance with a tight waistline), a large involvement of the lateral cavernous sinus space (lateral to the carotid artery), extensive anterior tumor projection, or lateral tumor projection into the middle fossa. ${ }^{37}$ Craniotomy can be limited in its ability to visualize intrasellar components of the tumor, especially if the planum sphenoidale is not drilled. However, doing such a transbasal exposure requires that the surgeon be prepared to repair the defect with duraplasty and a vascularized pericranial graft. The sella was frequently a site of residual tumor in our craniotomy group and rarely in approaches through the sella. General neurosurgeons approaching these tumours via a craniotomy in the future might mitigate this problem to an extent by greater exposures and the incorporation of angled endoscopes as an adjunct to the microscope. As well, the craniotomy approach allows access to only one cavernous sinus, whereas the BETS approach allows access to both parasellar spaces. In our opinion, the main limitation of the craniotomy approach is the result of approaching the critical structures, such as the optic nerves, chiasm, and the anterior cerebral artery complex, from the brain side of the arachnoid rather than the sellar side of the arachnoid. Craniotomy puts these critical structures at greater risk, particularly of perforating artery injuries from the anterior striate arteries and the recurrent artery of Huebner. This problem was evident in our data: the craniotomy group had major complications that manifested in much longer hospital stays.

The patient's clinical presentation, tumor anatomy, and tumor biology should be the primary dictates for the approach undertaken, rather than just the size of the lesion. Our results indicate that preoperatively, the surgeon must consider the areas prone to residual tumor because of a particular surgical approach. If the lesion is primarily midline, then, regardless of the degree of suprasellar extension, we advocate a midline approach to the lesion, transsphenoidally. When faced with a patient with a GPT with significant lateral extension or with the anterior cerebral complex encased, one should try to determine whether a major decompression of the optic apparatus can be achieved transsphenoidally without leaving a large amount of residual tumor in the suprasellar compartment. If this is possible, we now advocate approaching the patient initially transsphenoidally since the patient is most often concerned about restoration of his or her vision in most GPTs. Lateral extension to the lateral cavernous sinus space and into the temporal lobe is rarely symptomatic in our experience. If we think we cannot decompress the suprasellar compartment adequately, we consider craniotomy initially for optic decompression and because leaving a large suprasellar component of the tumor can put the patient at risk of hemorrhaging into the residual lesion, resulting in hypothalamic and optic compression. Because of efforts by our group and others ${ }^{20,38-41}$ to more extensively resect the skull base to better access the lesion in the suprasellar compartment, we have found BETS to be the most versatile approach.

\section{Degree of Tumor Resection}

Although the soft texture of most GPTs facilitates the resection of large volumes of tumor, our data show that surgical approach does play an important role in the degree of resection achievable with the tumours. In our study, a significantly greater degree of tumor resection was achieved with BETS (91\%) than with craniotomy $(63 \%)$ or with MTS $(63 \%)$. The BETS also resulted in a greater proportion of GTRs than craniotomy; the rates of GTR did not differ between MTS and craniotomy. Our GTR rates for BETS (21\%) and MTS (14\%) were comparable with the experience of large series of GPT ${ }^{3,5,42}$ (see Table 4). Although none of our patients in the craniotomy group achieved GTR, $17 \%$ of patients achieved near total excision (>90\% tumor-volume reduction), which we believe could have been due to the surgeon's desire to avoid complications. For patients with virgin tumours who had not received prior radiation, resection rates with BETS (93\%) were statistically superior to those for craniotomy (71\%), and MTS (71\%). Resection rates for the MTS and craniotomy groups were similar for these patients. Therefore, our findings suggest that receiving prior surgery and radiation did not contribute to the difference in resection rates observed for the BETS and MTS groups.

Cavernous sinus invasion has been suggested to portend incomplete tumor removal ${ }^{3}$; however our study found that rates of GTR were not statistically associated with cavernous sinus invasion.

Compared with the operating microscope, the endoscope offers several important advantages that likely explain the difference in degree of tumor resection. ${ }^{25,43,44}$ Since we used angled endoscope lenses and rotated the endoscope to allow surgical views of laterally and superiorly placed structures, we often identified parts of tumours that would not be seen with zero-degree endoscopes or the straight-line view of the microscope. Although lateral views are possible when mirrors are used with the microscope, we believe that the views with the endoscope are much better than those with mirrors and the microscope. Alternatively, neurosurgeons who are more comfortable with the microscopic approach could gain the advantage of endoscopic views by using angled endoscopes after completing resection with the microscope. We also placed the endoscope into the sellar, suprasellar, and parasellar spaces to view superior or superolateral or superoposterior extensions of the tumor. A close-up view at the junction of the tumor and the pituitary gland in the sella is much clearer, particularly with the newer high-definition television screens (Wide View by Storz, Tuttlingen, Germany), than the remote view with the operating microscope, and enhances the chance of tumor resection, gland preservation, and prevention of CSF leakage. The endoscopic technique eliminates the restriction of the surgeon's hand and the operating field imposed by the nasal speculum. In combination with the binostril technique that we developed, this technique allows a wider working angle and easier introduction of instruments. With all the approaches, including the endoscopic approach, we use three or four surgical instruments in the 


\section{Table 4: Summary of GPT literature}

\begin{tabular}{|c|c|c|c|c|c|c|c|c|}
\hline Reference & \# patients & Presentation & Surgical approaches & Resection rates & Complications & Deaths & Recurrences & $\begin{array}{l}\text { Post-op } \\
\text { Radiation }\end{array}$ \\
\hline $\begin{array}{l}\text { Cusimano et } \\
\text { al. 2012* }\end{array}$ & 72 & $\begin{array}{l}94 \% \text { impaired vision, } \\
47 \% \text { headache, } 89 \% \text { non- } \\
\text { functional }\end{array}$ & BETS, MTS, craniotomy & $\begin{array}{l}\text { BETS - 91\% } \\
\text { TSM }-63 \%, \\
\text { craniotomy - } 63 \%\end{array}$ & $\begin{array}{l}\text { 4.2\% pulmonary embolism, } \\
1.3 \% \text { deep vein thrombosis, } \\
1.3 \% \text { hydrocephalus, } 1.3 \% \\
\text { subdural hygroma, } 1.3 \% \\
\text { vasospasm, } 5.6 \% \\
\text { hematoma, } 1.3 \% \text { bacteremia }\end{array}$ & $1.3 \%$ & $26 \%$ & $26 \%$ \\
\hline $\begin{array}{l}\text { De Naiva } \\
\text { Peto } \text { et }_{\text {al }} \text {. } \\
2009^{54}\end{array}$ & 51 & $\begin{array}{l}\text { 74.5\% impaired vision, } \\
80 \% \text { hypopituitarism, } \\
76.4 \% \text { non-functional, } \\
15.6 \% \text { PRL adenoma, } 4 \% \\
\text { GH adenoma, } 2 \% \text { ACTH } \\
\text { adenoma }\end{array}$ & Endonasal transphenoidal & $\begin{array}{l}41 \% \text { GTR, } 20 \% \\
\text { achieved }>90 \% \\
\text { resection, 39\% } \\
\text { achieved }<90 \% \\
\text { resection }\end{array}$ & $\begin{array}{l}4 \% \text { hematoma, } 2 \% \text { CSF } \\
\text { leak, } 2 \% \text { right hemiparesis, } \\
4 \% \text { pulmonary embolus, } 6 \% \\
\text { sinusitis }\end{array}$ & $0 \%$ & $13.7 \%$ & $20 \%$ \\
\hline $\begin{array}{l}\text { Xue-Fei } \text { et al. } \\
2008{ }^{17}\end{array}$ & 54 & $\begin{array}{l}100 \% \text { impaired vision, } \\
72 \% \text { non-functional, } \\
1.8 \% \text { prolactinoma, } 9.3 \% \\
\text { GH adenoma, } 5.6 \% \\
\text { ACTH adenoma, } 5.5 \% \\
\text { PRL and GH adenoma }\end{array}$ & $\begin{array}{l}\text { Extended transnasal- } \\
\text { sphenoidal, } \\
\text { extended subfrontal } \\
\text { epidural and subepidural } \\
\text { combined, } \\
\text { trans-orbit-zygomatic- } \\
\text { pterional approach, trans- } \\
\text { anterior longitudinal } \\
\text { fissure approach, } \\
\text { combined, staged } \\
\end{array}$ & $\begin{array}{l}33.3 \% \text { GTR, } \\
51.9 \% \text { subtotal } \\
\text { removal, } 9.3 \% \\
\text { partial removal }\end{array}$ & $\begin{array}{l}92.6 \% \text { diabetes insipidus, } \\
16.7 \% \text { hypothalamic } \\
\text { injuries }\end{array}$ & $5.6 \%$ & $\begin{array}{l}5.5 \% \text { of patients } \\
(1.8 \% \mathrm{GH}, \\
3.6 \% \text { non- } \\
\text { functional })\end{array}$ & $\begin{array}{l}46 \% \\
\text { fractionated } \\
\text { radiotherapy, } \\
9.2 \% \text { gamma- } \\
\text { knife surgery }\end{array}$ \\
\hline $\begin{array}{l}\text { Mortini } \text { et al. } \\
2007^{3}\end{array}$ & 95 & $\begin{array}{l}\text { 86.3\% impaired vision, } \\
74 \% \text { non-functioning, } \\
10.5 \% \text { GH adenoma, } \\
10.5 \% \text { PRL adenoma, } \\
5.3 \% \text { TSH adenoma }\end{array}$ & $\begin{array}{l}\text { Sublabial, transseptal } \\
\text { transphenoidal, } \\
\text { frontopterional } \\
\text { transsylvian craniotomy, } \\
\text { fronto-orbito-zygomatic } \\
\text { craniotomy, enlarged } \\
\text { subfrontal craniotomy }\end{array}$ & $14.7 \%$ GTR & $\begin{array}{l}7.2 \% \text { bleeding residual, } \\
4.5 \% \text { visual worsening, } \\
2.7 \% \text { CSF rhinorrhea, } 0.9 \% \\
\text { hypothalamic syndrome, } \\
0.9 \% \text { hemorrhage, } 0.9 \% \\
\text { ischemia, } 0.9 \% \\
\text { opthalmoplegia, } 26.1 \% \\
\text { hypopituitarism, } 9.9 \% \\
\text { diabetes insipidus, } 2.7 \% \\
\text { transient hyponatremia } \\
\end{array}$ & $3.2 \%$ & $15.7 \%$ & $33.6 \%$ \\
\hline $\begin{array}{l}\text { Goel } 2004 \text { et } \\
\text { al. } .^{2}\end{array}$ & 118 & $\begin{array}{l}94 \% \text { impaired vision, } \\
80 \% \text { headaches, } 100 \% \\
\text { non-functioning }\end{array}$ & $\begin{array}{l}\text { Transphenoidal surgery, } \\
\text { transcranial surgery }\end{array}$ & $\begin{array}{l}29.6 \% \text { GTR, } \\
40.7 \% \text { small } \\
\text { residue, } 29.6 \% \\
\text { large residue } \\
\end{array}$ & Unclear & $2.5 \%$ & Unclear & $27.9 \%$ \\
\hline $\begin{array}{l}\text { Garibi } \text { et al. } \\
2002^{1}\end{array}$ & 43 & $\begin{array}{l}60.5 \% \text { impaired vision, } \\
55.8 \% \text { headaches, } 88 \% \\
\text { hypopituitarism, } 25.6 \% \\
\text { GH adenoma, } 12.6 \% \\
\text { PRL adenoma } \\
\end{array}$ & Transseptal transphenoidal & $27 \%$ GTR & $\begin{array}{l}18.8 \% \text { transient diabetes } \\
\text { insipidus, } 14.6 \% \text { meningitis } \\
\text { with CSF fistula, } 8.3 \% \\
\text { definitive diabetes insipidus }\end{array}$ & $4.65 \%$ & Unclear & $37 \%$ \\
\hline $\begin{array}{l}\text { Alleyne } \text { et al. } \\
2002^{42}\end{array}$ & 10 & $\begin{array}{l}90 \% \text { impaired vision, } \\
50 \% \text { hypopituitarism, } \\
100 \% \text { non-functional, } \\
50 \% \text { headaches }\end{array}$ & $\begin{array}{l}\text { Combined simultaneous } \\
\text { transphenoidal and } \\
\text { pterional craniotomy }\end{array}$ & $\begin{array}{l}40 \% \text { achieved } \\
\text { GTR, } 20 \% \\
\text { achieved }>90 \% \\
\text { removal, } 40 \% \\
\text { achieved } 80-90 \% \\
\text { removal } \\
\end{array}$ & $\begin{array}{l}20 \% \text { diabetes insipidus, } \\
10 \% \text { hydrocephalus, } 10 \% \\
\text { caudate infarct, } 10 \% \\
\text { hypothyroidism }\end{array}$ & $0 \%$ & Unclear & $20 \%$ \\
\hline $\begin{array}{l}\text { Goel } \text { et al. } \\
1996^{18}\end{array}$ & 30 & $\begin{array}{l}72 \% \text { impaired vision, } \\
67 \% \text { headaches, } 93 \% \\
\text { non-functional, 3\% GH } \\
\text { adenoma, 3\% TSH } \\
\text { adenoma }\end{array}$ & $\begin{array}{l}\text { Frontal craniotomy, } \\
\text { bifrontal craniotomy, } \\
\text { frontotemporal } \\
\text { craniotomy, trans-frontal } \\
\text { air sinus craniotomy, } \\
\text { transphenoidal surgery } \\
\end{array}$ & $\mathrm{N} / \mathrm{A}$ & Unclear & $20 \%$ & Unclear & $73 \%$ \\
\hline $\begin{array}{l}\text { King et al. } \\
1996^{8}\end{array}$ & 11 & $\begin{array}{l}91 \% \text { impaired vision, } \\
45 \% \text { headache, } 72 \% \text { non- } \\
\text { functional, } 18 \% \text { PRL } \\
\text { adenoma, } 9 \% \text { ACTH } \\
\text { adenoma }\end{array}$ & $\begin{array}{l}\text { Transnasal transphenoidal, } \\
\text { fronto-temporal } \\
\text { craniotomy }\end{array}$ & $\begin{array}{l}64 \% \text { achieved } \\
>90 \% \text { resection }\end{array}$ & $\begin{array}{l}18 \% \text { CSF leak, } 9 \% \text { CN } 3 \\
\text { palsy, } 18 \% \text { infarct, } 9 \% \\
\text { pulmonary embolus, } 9 \% \\
\text { hemispheric swelling, } 18 \% \\
\text { hydrocephalus }\end{array}$ & $18 \%$ & $0 \%$ & $\mathrm{~N} / \mathrm{A}$ \\
\hline $\begin{array}{l}\text { Pia et al. } \\
1985^{16}\end{array}$ & 77 & Unclear & $\begin{array}{l}\text { Transfrontal craniotomy, } \\
\text { combined transfrontal- } \\
\text { transphenoidal approach, } \\
\text { fronto-temporal, temporal } \\
\text { and bifrontal craniotomy } \\
\end{array}$ & Unclear & $\begin{array}{l}\text { Increased visual, } \\
\text { oculomotor disturbances, } \\
\text { diabetes insipidus, and } \\
\text { mental disturbances }\end{array}$ & $14 \%$ & $29 \%$ & $\begin{array}{l}29 \% \text { (all those } \\
\text { who recurred) }\end{array}$ \\
\hline $\begin{array}{l}\text { Symon et al. } \\
1979^{15}\end{array}$ & 16 & $\begin{array}{l}100 \% \text { impaired vision, } \\
31 \% \text { hypopituitarism }\end{array}$ & $\begin{array}{l}\text { Frontal or frontotemporal } \\
\text { craniotomy }\end{array}$ & Unclear & Unclear & $\begin{array}{l}19 \% \\
\text { immediate } \\
\text { post-op, } \\
13 \%<6 \mathrm{mo} \\
\text { surgery, }\end{array}$ & Unclear & unclear \\
\hline
\end{tabular}

* Results are reported for all patients combining 3 surgical approaches, unless indicated in the table. See results text for breakdown according to surgical procedure . BETS $=$ Binasal endoscopic transphenoidal approach, TSM = transphenoidal microscopic approach, $\mathrm{PRL}=\mathrm{Prolactin}, \mathrm{GH}=\mathrm{Growth}$ Hormone, $\mathrm{ACTH}=$ Adrenocorticotropin Hormone, GTR $=$ Gross Total Resection, $\mathrm{CSF}=$ Cerebrospinal Fluid, TSH $=$ Thyroid Stimulating Hormone, $\mathrm{CN}=$ Cranial Nerve, $<=$ less than 
surgical field. We believe that these advantages account for the better resections with BETS.

\section{Surgical Complications}

A comparison of surgical complications among different series of patients is very difficult, given the difficulty of comparing the characteristics of tumours and patients among series. Jane and Laws ${ }^{7}$ reported a mortality of less than $0.5 \%$, major complications of $1.5 \%$, and minor complications of $6.5 \%$ in a large series of unselected transsphenoidal surgeries for pituitary adenomas. Other authors ${ }^{2,5,14,15,18}$ (see Table 4) reported significantly higher morbidity and mortality associated with GPT. The most common complications in several series ${ }^{1,3}$ were diabetes insipidus and hypopituitarism. Several authors $2,3,14,15,18$ described residual sellar and suprasellar tumours as being responsible for significant morbidity and mortality. Our series shows that the craniotomy group, which tended to have more residual sellar tumours, also had more complications than the BETS or MTS groups, particularly more severe complications. However, only one patient treated with craniotomy in our study died. CSF leakage is common during transsphenoidal surgery, and should be anticipated and a repair planned for all patients. In our series, we frequently used a multilayered fascia lata and bone repair, often with vascularized mucosal flaps for CSF leaks. In cases where fascia lata repairs were insufficient, reoperation for repair was considered.

Given the variability of tumor morphology, consistency and texture, there is likely no reliable specific cutoff point at which complications rise and cure rates drop based on size of tumor alone, but rather GPTs are just one of the extremes of a spectrum of tumours. Although sheer size is related to invasion of the parasellar and suprasellar space, ${ }^{1}$ we believe that complications are related more to the tumor's invasion of these structures and the penetration of the dura and arachnoid than to the tumor's size alone. Tumor softness and degree of fibrosity is also an important characteristic determining surgical resectability.

\section{Outcomes}

In the last decade, several authors ${ }^{44-46}$ have reported good outcomes with the endoscopic transsphenoidal approach and its better remission rates, fewer complications, shorter hospital stays, less surgical time, and less postoperative pain than the conventional MTS approach. Our study is unique because it focuses on giant tumours resected with a purely endoscopic binasal approach and compares tumor-volume reduction and surgical outcomes of these approaches.

\section{Visual outcome}

Like others, ${ }^{1,3,14-16,18}$ we found that GPTs are primarily nonfunctioning and that their suprasellar extensions causing visual field deficits were the commonest mode of presentation in our series and others. Previous studies ${ }^{3,14,15}$ have shown improvements in visual function after surgery for GPTs in $50-89 \%$ of patients. Our study found similar rates of improvement for the craniotomy (72\%) and MTS (86\%) groups, and slightly higher rates of improvement for the BETS group (96\%). None of our patients had visual worsening postoperatively. However, unlike previous results, ${ }^{3}$ we did not find a statistical advantage for
BETS specifically for the improvement of visual deficits, although there was a trend towards significance.

\section{Mass Effects}

Not surprisingly, our study showed that all types of surgery resulted in almost universal improvements (82-100\%) in headaches in patients with GPT. To our knowledge, the rate of improvement in headaches after surgery has been reported in only one other study. ${ }^{47}$ Patients, surgeons, and radiation oncologists must consider this important outcome in their decision-making. The significant decompression that can be achieved with surgery cannot be matched by radiotherapy and should be an important consideration when individualizing treatment to the patient's needs.

\section{Endocrine Outcome}

Consistent with those of other series, the tumours in our series were overwhelmingly nonfunctional, but the small sample sizes preclude any definitive statements about the outcomes of functional GPTs. However, their tendency to invade parasellar and suprasellar structures may portend a poorer prognosis for the endocrine function of patients with GPTs than that of those with their smaller counterparts.

Given the size of these neoplasms, it is not unexpected that large numbers of these patients have hypopituitarism. What is surprising is that $41 \%$ of our patients in the BETS group had endocrine improvement, a rate similar to the rates reported in large series ${ }^{7}$ of unselected micro- and macroadenomas. In our series, we were not able to show significant differences in the rates of permanent diabetes insipidus or requirement for new hormone replacement among the three surgical groups. This finding is not surprising because it is extremely difficult, if not impossible, to properly visualize the normal gland or pituitary stalk preoperatively in patients with these large tumours.

\section{Tumor Biology, Recurrences and Adjuvant Therapy}

Chacko et $\mathrm{al}^{21}$ studied a series of 28 GPTs and found that all the tumours had typical histological features of pituitary adenoma. Of the 23 clinically nonfunctional adenomas, 18 were gonadotroph tumours, 4 were null-cell adenomas, and 1 was a silent corticotroph adenoma. The Ki-67 indices as measured by MIB-1 antibody were low ranging $(0.1-2.0 \%)$. The mean topoisomerase-labeling index was also low $(0.75 \%)$. Microvessel density ranged from $0.42 \%$ to $5.55 \%$, and there was moderately intense immunostaining for vascular endothelial growth factor. The authors concluded that GPTs are invasive, but slow-growing, histologically benign lesions.

Thirty-four of our patients had estimates for their MIB-1 indices (14 BETS, 17 craniotomy, 3 MTS). Our data show that the mean labeling index of all tumours was $2.7 \%$ (median $2 \%$, range $1-10 \%$ ); 16 of the tumours had a labeling index of $1 \%$, thus confirming the findings of Chacko et $\mathrm{al}^{21}$ Our analyses also indicated that the MIB-1 indices were similar for patients with recurring and nonrecurring tumours, which suggests that recurrences would be rare if a complete resection could be obtained and that recurrences could be delayed with initially incomplete resection of the tumours. Our results support the implication that for many patients, surgery to decompress critical 
structures as much as possible, followed by observation may provide satisfactory outcomes for long periods of time. Such an approach could delay the potentially negative long-term consequences of radiating patients with residual nonfunctioning adenomas.

Consistent with these findings, the recurrences in our series occurred primarily in patients with initially incomplete tumor resections or in those with silent subtype 2 or 3 tumours, which are known for their biological aggressivity. ${ }^{48,49}$ Adjuvant radiotherapy was more common after craniotomy surgery, as were the rates of prior radiotherapy. Although radiotherapy can have a significant effect on preventing recurrences, ${ }^{30,50}$ radiotherapy carries risks of new endocrinopathy, cognitive impairment, and induction of new neoplasms after five to ten years. ${ }^{22,23,51-53}$ Given the low MIB-1 indices of our tumours, we elected to delay exposure to stereotactic fractionated radiotherapy for patients who had good decompression, or with incomplete resection of their tumor, until there was evidence of residual tumor regrowth.

\section{Limitations}

Our study has several limitations that are typical of retrospective analyses. First, more patients in the craniotomy group, as compared to the BETS group, received prior radiation therapy, which may have changed the consistency of the tumor and thus affected the rates of tumor resection. To try to account for this, we evaluated the degree of tumor resection among the groups in patients with virgin tumours who did not receive radiation therapy. Binasal endoscopic transsphenoidal still offered a greater degree of tumor resection than craniotomy, but not greater than with MTS. This finding suggests that prior radiation and prior surgery, or a confounding factor related to both of these, may have contributed to the observed differences in resection rates between BETS and MTS, although a type II error may also explain this difference. Although baseline differences between the three groups were minimal, it is conceivable that differences in outcomes could be due to intrinsic differences in the tumours, patients, or the surgeons who operated on the patients. An uncontrolled factor in any retrospective study, including this one, is that the differences in outcomes may have been due to the experiences of the individual surgeons rather than the technique. Although all surgeons in the study were highly experienced pituitary surgeons, this remains a possibility and thus may limit generalizability. Ideally a randomized controlled trial (RCT) would be the best way to disentangle these confounding effects, but we believe that such an RCT would not be acceptable to surgeons or patients and likely never be done. Lastly, although our average follow-up of 6.16 years is longer than most reported series of pituitary surgery, $3,8,15,42,46,54$ proliferation indices and the natural history of these tumours demands that follow-up continue for many more years.

\section{CONCLusion}

The surgical management of patients with GPT is challenging, regardless of the surgical approach used. Our study suggests that excellent oncologic and clinical outcomes can be achieved with BETS for patients with GPT and that compared with craniotomy and MTS, BETS offers the best chance of tumor removal. Care of these patients should be individualized to the patient, the biology and pathology of the lesion, and the experience of the surgeon and the institution.

\section{ACKNOWLEDGEMENTS}

The authors thank Sharon Nancekivell for her editorial work.

\section{REFERENCES}

1. Garibi J, Pomposo I, Villar G, Gaztambide S. Giant pituitary adenomas: clinical characteristics and surgical results. $\mathrm{Br} \mathrm{J}$ Neurosurg. 2002 Apr;16(2):133-9.

2. Goel A, Nadkarni T, Muzumdar D, Desai K, Phalke U, Sharma P. Giant pituitary tumours: a study based on surgical treatment of 118 cases. Surg Neurol. 2004 May;61(5):436-45; discussion 45-6.

3. Mortini P, Barzaghi R, Losa M, Boari N, Giovanelli M. Surgical treatment of giant pituitary adenomas: strategies and results in a series of 95 consecutive patients. Neurosurgery. 2007 Jun;60(6): 993-1002; discussion 3-4.

4. Fisher BJ, Gaspar LE, Noone B. Giant pituitary adenomas: role of radiotherapy. Int J Radiat Oncol Biol Phys. 1993 Mar 15;25(4): 677-81.

5. Krisht AF. Giant invasive pituitary adenomas: management plan. Contemp Neurosurg. 1999;21:1-6.

6. Laws ER, Jane JA, Jr. Neurosurgical approach to treating pituitary adenomas. Growth Horm IGF Res. 2005 Jul;15 Suppl A:S36-41.

7. Jane JA, Jr., Laws ER, Jr. The surgical management of pituitary adenomas in a series of 3,093 patients. J Am Coll Surg. 2001 Dec;193(6):651-9.

8. King WA, Rodts GE, Becker DP, Mc Bride DQ. Microsurgical Management of Giant Pituitary Tumours. Skull Base Surg. 1996; 6(1): 17-26.

9. Ciric I, Mikhael M, Stafford T, Lawson L, Garces R. Transsphenoidal microsurgery of pituitary macroadenomas with longterm follow-up results. J Neurosurg. 1983 Sep;59(3):395-401.

10. Jefferson G. Extrasellar Extensions of Pituitary Adenomas: (Section of Neurology). Proc R Soc Med. 1940 May;33(7): 433-58.

11. Nakane T, Kuwayama A, Watanabe M. Transsphenoidal approach to pituitary adenomas with suprasellar extension. Surg Neurol. 1981;16:225-9.

12. Wilson CB. Neurosurgical management of large and invasive pituitary tumours. In: Tindall FT, Collins WF, editors. Clinical Management of Pituitary Disorders. New York: Raven Press; 1979. p. 355-42.

13. Bakay L. The results of 300 pituitary adenoma operations (Prof. Herbert Olivecrona's series). J Neurosurg. 1950 May;7(3): 240-55.

14. Mohr G, Hardy J, Comtois R, Beauregard H. Surgical management of giant pituitary adenomas. Can J Neurol Sci. 1990 Feb;17(1): 62-6.

15. Symon L, Jakubowski J, Kendall B. Surgical treatment of giant pituitary adenomas. J Neurol Neurosurg Psychiatry. 1979 Nov; 42(11):973-82.

16. Pia HW, Grote E, Hildebrand G. Giant pituitary adenomas. Neurosurg Rev. 1985;8(3-4):207-20.

17. Xue-Fei S, Yong-Fei W, Shi-Qi L, et al. Microsurgical treatment for giant and irregular pituitary adenomas in a series of 54 consecutive patients. Br J Neurosurg. 2008 Oct;22(5):636-48.

18. Goel A, Nadkarni T. Surgical management of giant pituitary tumours--a review of 30 cases. Acta Neurochir (Wien). 1996; 138(9):1042-9.

19. Jefferson A. Chromophobe pituitary adenomata the size of the suprasellar portion in relation to the safety of operation (Abstract). J Neurol Neurosurg Psychiatry. 1969;32:633.

20. Cavallo LM, de Divitiis O, Aydin S, et al. Extended endoscopic endonasal transsphenoidal approach to the suprasellar area: anatomic considerations--part 1. Neurosurgery. 2008 Jun;62(6 Suppl 3):1202-12. 
21. Chacko G, Chacko AG, Lombardero M, et al. Clinicopathologic correlates of giant pituitary adenomas. J Clin Neurosci. 2009 May;16(5):660-5.

22. Tsang RW, Brierley JD, Panzarella T, et al. Radiation therapy for pituitary adenoma: treatment outcome and prognostic factors. Int J Radiat Oncol Biol Phys. 1994 Oct 15;30(3):557-65.

23. Tsang RW, Brierley JD, Panzarella T, et al. Role of radiation therapy in clinical hormonally-active pituitary adenomas. Radiother Oncol. 1996 Oct:41(1):45-53.

24. Jho HD, Carrau RL, Ko Y, Daly MA. Endoscopic pituitary surgery: an early experience. Surg Neurol. 1997 Mar;47(3):213-22; discussion 22-3.

25. Cusimano MD, Fenton RS. The technique for endoscopic pituitary tumor removal. Neurosurg Focus. 1996 Jul 15;1(1):e1; discussion $\mathrm{p}$ following e3.

26. Cavallo LM, Prevedello DM, Solari D, et al. Extended endoscopic endonasal transsphenoidal approach for residual or recurrent craniopharyngiomas. J Neurosurg. 2009 Sep;111(3):578-89.

27. de Notaris M, Cavallo LM, Prats-Galino A, et al. Endoscopic endonasal transclival approach and retrosigmoid approach to the clival and petroclival regions. Neurosurgery. 2009 Dec;65(6 Suppl):42-50; discussion -2.

28. Ceylan S, Koc K, Anik I. Extended endoscopic approaches for midline skull-base lesions. Neurosurg Rev. 2009 Jul;32(3):30919; discussion 18-9.

29. AAlahmadi H, Vachhrajani S, Cusimano MD. The natural history of brain contusion: an analysis of radiological and clinical progression. J Neurosurg. 2010;112(5):1139-45.

30. Kong DS, Lee JI, Lim do H, et al. The efficacy of fractionated radiotherapy and stereotactic radiosurgery for pituitary adenomas: long-term results of 125 consecutive patients treated in a single institution. Cancer. 2007 Aug 15;110(4):854-60.

31. Shamim MS, Bari ME, Khursheed F, Jooma R, Enam SA. Pituitary adenomas: presentations and outcomes in a South Asian country. Can J Neurol Sci. 2008 May;35(2):198-203.

32. Shin KH, Moon SH, Suh JS, Yang WI. Tumor volume change as a predictor of chemotherapeutic response in osteosarcoma. Clin Orthop Relat Res. 2000 Jul(376):200-8.

33. Vieira JO, Jr., Cukiert A, Liberman B. Evaluation of magnetic resonance imaging criteria for cavernous sinus invasion in patients with pituitary adenomas: logistic regression analysis and correlation with surgical findings. Surg Neurol. 2006 Feb;65(2): 130-5; discussion 5

34. Bahmer FA, Hantirah S, Baum HP. Rapid and unbiased estimation of the volume of cutaneous malignant melanoma using Cavalieri's principle. Am J Dermatopathol. 1996 Apr;18(2): $159-64$.

35. Knosp E, Steiner E, Kitz K, Matula C. Pituitary adenomas with invasion of the cavernous sinus space: a magnetic resonance imaging classification compared with surgical findings. Neurosurgery. 1993 Oct;33(4):610-7; discussion 7-8.

36. Hardy J. Transphenoidal microsurgery of the normal and pathological pituitary. Clin Neurosurg. 1969;16:185-217.

37. Youssef AS, Agazzi S, van Loveren HR. Transcranial surgery for pituitary adenomas. Neurosurgery. $2005 \mathrm{Jul} ; 57$ (1 Suppl):168-75; discussion -75
38. de Notaris M, Esposito I, Cavallo LM, et al. Endoscopic endonasal approach to the ethmoidal planum: anatomic study. Neurosurg Rev. 2008 Jul;31(3):309-17.

39. Aydin S, Cavallo LM, Messina A, et al. The endoscopic endonasal trans-sphenoidal approach to the sellar and suprasellar area. Anatomic study. J Neurosurg Sci. 2007 Sep;51(3):129-38.

40. de Divitiis E, Cavallo LM, Cappabianca P, Esposito F. Extended endoscopic endonasal transsphenoidal approach for the removal of suprasellar tumours: Part 2. Neurosurgery. 2007 Jan;60(1):4658; discussion -9 .

41. Laufer I, Anand VK, Schwartz TH. Endoscopic, endonasal extended transsphenoidal, transplanum transtuberculum approach for resection of suprasellar lesions. J Neurosurg. 2007 Mar;106(3):400-6.

42. Alleyne $\mathrm{CH}$, Jr., Barrow DL, Oyesiku NM. Combined transsphenoidal and pterional craniotomy approach to giant pituitary tumours. Surg Neurol. 2002 Jun;57(6):380-90; discussion 90.

43. de Divitiis E. Endoscopic transsphenoidal surgery: stonein-the-pond effect. Neurosurgery. 2006 Sep;59(3):512-20; discussion -20

44. Kabil MS, Eby JB, Shahinian HK. Fully endoscopic endonasal vs. transseptal transsphenoidal pituitary surgery. Minim Invasive Neurosurg. 2005 Dec;48(6):348-54.

45. Cappabianca P, Alfieri A, Colao A, Ferone D, Lombardi G, de Divitiis E. Endoscopic endonasal transsphenoidal approach: an additional reason in support of surgery in the management of pituitary lesions. Skull Base Surg. 1999;9(2):109-17.

46. Rudnik A, Zawadzki T, Galuszka-Ignasiak B, et al. Endoscopic transsphenoidal treatment in recurrent and residual pituitary adenomas--first experience. Minim Invasive Neurosurg. 2006 Feb;49(1):10-4.

47. Ebersold MJ, Quast LM, Laws ER, Jr., Scheithauer B, Randall RV. Long-term results in transsphenoidal removal of nonfunctioning pituitary adenomas. J Neurosurg. 1986 May;64(5):713-9.

48. Horvath E, Kovacs K, Smyth HS, Cusimano M, Singer W. Silent adenoma subtype 3 of the pituitary--immunohistochemical and ultrastructural classification: a review of 29 cases. Ultrastruct Pathol. 2005 Nov-Dec;29(6):511-24.

49. Sanno N, Teramoto A, Osamura RY. Clinical and cytofunctional classification of pituitary adenomas: proposal of a new classification. Acta Neurochir (Wien). 1996;138(10):1186-92.

50. Selch MT, Gorgulho A, Lee SP, et al. Stereotactic radiotherapy for the treatment of pituitary adenomas. Minim Invasive Neurosurg. 2006 Jun;49(3): 150-5

51. Fisher BJ, Gaspar LE, Noone B. Radiation therapy of pituitary adenoma: delayed sequelae. Radiology. 1993 Jun;187(3):843-6.

52. Littley MD, Shalet SM, Beardwell CG, Robinson EL, Sutton ML. Radiation-induced hypopituitarism is dose-dependent. Clin Endocrinol (Oxf). 1989 Sep;31(3):363-73.

53. Chang EF, Zada G, Kim S, et al. Long-term recurrence and mortality after surgery and adjuvant radiotherapy for nonfunctional pituitary adenomas. J Neurosurg. 2008 Apr;108 (4):736-45.

54. de Paiva Neto MA, Vandergrift A, Fatemi N, et al. Endonasal transsphenoidal surgery and multimodality treatment for giant pituitary adenomas. Clin Endocrinol (Oxf). 2010;72(4):512-9. 